\title{
Growth and nutrient removal of Chlorella vulgaris in ammonia-reduced raw and anaerobically-digested piggery wastewaters
}

\author{
Gyutae Kwon ${ }^{1}$, Ji-Hyun Nam², Dong-Min Kim ${ }^{1}$, Chulwoo Song ${ }^{3}$, Deokjin Jahng ${ }^{+}$ \\ ${ }^{1}$ Department of Environmental Engineering and Energy, Myongji University, Yongin 17058, Republic of Korea \\ ${ }^{2}$ Water Supply and Sewerage Research Division, National Institute of Environmental Research, Incheon 22689, Republic of Korea \\ ${ }^{3}$ BKT Co. Ltd., Daejeon 34109, Republic of Korea
}

\begin{abstract}
This study was aimed to investigate the possibility of using raw and anaerobically-digested piggery wastewater as culture media for a green microalga Chlorella vulgaris (C. vulgaris). Due to high concentration of ammonia and dark color, the microalga did not grow well in this wastewater. In order to solve this problem, air stripping and NaOCl-treatment were applied to reduce the concentration of $\mathrm{NH}_{3}-\mathrm{N}$ and the color intensity from the wastewater. Algal growth was monitored in terms of specific growth rate, biomass productivity, and nutrient removal efficiency. As a result, $C$. vulgaris grew without any sign of inhibition in air-stripped and 10-folds diluted anaerobically-digested piggery wastewater with enhanced biomass productivity of $0.57 \mathrm{~g} / \mathrm{L} \cdot \mathrm{d}$ and nutrient removal of $98.7-99.8 \%$ for $\mathrm{NH}_{3}-\mathrm{N}$ and $41.0-62.5 \%$ for total phosphorus. However, $\mathrm{NaOCl}$-treatment showed no significant effect on growth of $C$. vulgaris, although dark color was removed greatly. Interestingly, despite that the soluble organic concentration after air stripping was still high, the biomass productivity was 4.4 times higher than BG-11. Moreover, air stripping was identically effective for raw piggery wastewater as for anaerobic digestate. Therefore, it was concluded that air stripping was a very effective method for culturing microalgae and removing nutrients from raw and anaerobically-digested piggery wastewaters.
\end{abstract}

Keywords: Air stripping, Ammonia, Anaerobic digestate of piggery wastewater, Biomass productivity, Chlorella vulgaris, Nutrient removal

\section{Introduction}

Piggery wastewater is one of the most-produced wastewaters throughout the world [1-2]. In Korea, piggery wastewater accounted for approximately $53 \%$ of livestock excreta, and more than 32 million tons of piggery wastewater were produced in 2015 [3]. Piggery wastewater contains not only organic matters but also nitrogen $(\mathrm{N})$ and phosphorus (P) that cause eutrophication when discharged into water bodies $[1,2,4,5]$. Piggery wastewater is frequently subjected to anaerobic digestion using acid-forming and methane-producing microorganisms [4, 6-7], by which organic matters are degraded, resulting in the reduction of volatile suspended solids and chemical oxygen demand (COD). However, nitrogen and phosphorus are not removed during anaerobic digestion albeit that trace amounts of both nutrients are absorbed by microbial cells for growth $[4,8,9]$. The nitrogen in anaerobic digestate of piggery excreta is mainly ammonia which is toxic to living organisms [9]. According to literatures [4, 10-11], anaerobically-digested piggery wastewater contains 1,196-3,141 mg/L of ammoniacal nitrogen and is known to be hardly treated by biological treatment [12].

Many studies have demonstrated that microalgae provide a great potential for removing inorganic nitrogen and phosphorus from wastewater [4, 13-16]. The main mechanism of nutrient removal by microalgae is assimilatory uptake into the cell [13, 17-18]. Microalgae provide other advantages in wastewater treatment, including no need for carbon source because of photosynthetic fixation of carbon dioxide, the possibility of utilizing algal biomass as a fertilizer, the discharge of oxygenated effluent into the water body, and conversion of algal biomass to biodiesel and hydrogen [4,

Received December 20, 2018 Accepted March 13, 2019

${ }^{\dagger}$ Corresponding author

Email: djahng@mju.ac.kr

Tel: +82-31-330-6690 Fax: +82-31-336-6336

ORCID: 0000-0001-6149-7442

Copyright (C) 2020 Korean Society of Environmental Engineers 
12-13]. Thus, the utilization of wastewater as an inexpensive medium for microalgae cultivation could achieve the dual goals of wastewater treatment and biomass/bioenergy production. The most-widely-used microalgae for nutrient removal are species of Chlorella [13, 15, 19-22], Scenedesmus [4, 15, 22-27], and Spirulina [14]. In particular, Chlorella vulgaris (C. vulgaris) is known to show a high resistance to organic matters and stable growth in various wastewaters [2, 19]. Also, phosphorus, nitrogen and organic matters can be removed at the same time [2, 19, 21]. In terms of bioenergy production, $C$. vulgaris contains high concentration of palmitic acid and linolenic acid, which are suitable for biodiesel production [28]. Although, Chlorella sp. and Scenedesmus sp. are known to grow well in the presence of high concentrations of ammonia and nitrate [19], concentration of ammonia in anaerobic digestate of piggery wastewater is too high for those microalgae to grow. A high level of ammonia is known to retard the growth of microalgae by disturbing the photosynthesis and nitrate uptake [29-33].

Many studies employed 5-40 folds dilution as a pre-treatment strategy to decrease concentrations of inorganic nutrients (ammonia toxicity), turbidity, and color (light limitation) in raw and anaerobically-digested piggery wastewater prior to cultivation of green microalgae [1-2, 4-5, 34-35]. Also physicochemical pre-treatment technologies were adopted prior to cultivation of green microalgae by using filtration [4, 34, 36], coagulation [31, 36], air stripping [36], $\mathrm{NaOCl}$ treatment [34], and ozonation [24, 29].

Ammonia can specifically be removed from wastewater by biological, physical, chemical, and combinations of these methods. Available technologies include adsorption, chemical precipitation, reverse osmosis, ion exchange, air stripping, breakpoint chlorination and biological nitrification and denitrification [37-38]. Among these technologies, air stripping is known to be very efficient for removing ammonia. Bonmati and Flotats [39] reported that air stripping provided many advantages when used for pre-treating anaerobically-digested piggery wastewater, and ammonia removal efficiency was very dependent on the characteristics of piggery wastewater. Cheng et al. [40] also commented that air stripping might be an effective option for the piggery wastewater containing a high concentration of ammonia (854 mg/L). The breakpoint chlorination is a commonly applied and well-known method for removing the ammonia and color [24].

For removing strong color, it has been reported that wastewater can be treated with oxidizing agents (e.g., $\mathrm{NaOCl}, \mathrm{H}_{2} \mathrm{O}_{2}, \mathrm{O}_{3}$, etc.) [24, 34, 41-43]. Recently, NaOCl-treated domestic, dairy and piggery wastewaters were used for Chlorella cultivation [5, 44]. Other studies suggested that nutrients was separated from the wastewater containing colored substances by using coagulants, flocculants, and adsorbents and then added to the microalgae culture medium [30, 35, 41-42]. In previous studies on low-strength wastewater treatment using microalgal cells, concentrations of total nitrogen (TN) and total phosphorus (TP) were 25.4-53.2 mg/L and 1.2-12.2 mg/L, respectively [15, 23, 45-47]. A few studies have dealt with microalgae cultivation as a strategy for treating anaerobically-digested piggery wastewater $[4,36]$. In case of high-strength wastewater containing various inhibitors that hinder the algal growth and nutrients removal, dilution method could be a solution overcoming this problem. However, information on effects of different pre-treatment methods for high-strength wastewater on the growth of microalgae and nutrient removal is not sufficient.

In this study, ammonia concentration and intensity of color of the anaerobic digestate of piggery wastewater were reduced by air stripping and $\mathrm{NaOCl}$ treatment. $C$. vulgaris was incubated under $50 \mu \mathrm{mol} / \mathrm{m}^{2}$ s of continuous light illumination so that both mixotrophic and autotrophic growth were enabled. The cells of $C$. vulgaris were grown in these pre-treated digestates to determine growth kinetics. Finally, nitrogen and phosphorus removal by algal growth was analyzed. Based on these results, pre-treatment methods for the cultivation of $C$. vulgaris in anaerobically-digested piggery wastewater were suggested.

\section{Materials and Methods}

\subsection{Microalgal Strain and Culture Conditions}

The microalgal strain used in this study was $C$. vulgaris KCTC AG10032 obtained from the Biological Resource Center of the Korea Research Institute of Bioscience and Biotechnology. C. vulgaris was maintained in the Blue-Green (BG-11) medium consisting of $\mathrm{NaNO}_{3}(1.5 \mathrm{~g} / \mathrm{L}), \mathrm{K}_{2} \mathrm{HPO}_{4}(40 \mathrm{mg} / \mathrm{L}), \mathrm{MgSO}_{4} \cdot 7 \mathrm{H}_{2} \mathrm{O}(75 \mathrm{mg} / \mathrm{L})$, $\mathrm{CaCl}_{2} \cdot 2 \mathrm{H}_{2} \mathrm{O}(36 \mathrm{mg} / \mathrm{L}), \mathrm{Na}_{2} \mathrm{CO}_{3}(20 \mathrm{mg} / \mathrm{L})$ and $\mathrm{FeCl}_{3} \cdot 6 \mathrm{H}_{2} \mathrm{O}(3.15$ $\mathrm{mg} / \mathrm{L})$, citric acid $(6 \mathrm{mg} / \mathrm{L}$ ) and $1 \mathrm{~mL} / \mathrm{L}$ of trace elements solution containing $\mathrm{H}_{3} \mathrm{BO}_{3}(2.86 \mathrm{mg} / \mathrm{L}), \mathrm{MnCl}_{2} \cdot 4 \mathrm{H}_{2} \mathrm{O}$ (1.81 mg/L), $\mathrm{ZnSO}_{4}$. $7 \mathrm{H}_{2} \mathrm{O}(0.22 \mathrm{mg} / \mathrm{L}), \mathrm{Na}_{2} \mathrm{MoO}_{4} \cdot 2 \mathrm{H}_{2} \mathrm{O}(0.39 \mathrm{mg} / \mathrm{L}), \mathrm{CuSO}_{4} \cdot 5 \mathrm{H}_{2} \mathrm{O}(0.08$ $\mathrm{mg} / \mathrm{L})$ and $\mathrm{Co}\left(\mathrm{NO}_{3}\right)_{2} \cdot 6 \mathrm{H}_{2} \mathrm{O}(0.05 \mathrm{mg} / \mathrm{L})$. The initial $\mathrm{pH}$ of the medium was adjusted to $\mathrm{pH}$ 6.8. Pre-cultured algal suspension $\left(2-3 \times 10^{8}\right.$ cells $/ \mathrm{mL}$ ) was inoculated at $10 \%(\mathrm{v} / \mathrm{v})$ ratio into $200 \mathrm{~mL}$ BG-11 medium contained in a $500 \mathrm{~mL}$ Erlenmeyer flask. Then the flask was incubated at $25^{\circ} \mathrm{C}$ and $50 \mu \mathrm{mol} / \mathrm{m}^{2} \cdot \mathrm{s}$ of continuous cool-white fluorescent light illumination with rotation at $150 \mathrm{rpm}$. Although additional carbon dioxide or oxygen was not supplied, these gases contained in ambient air might be dissolved into the medium because flasks were closed with cotton plugs. Cells grown in this flask were inoculated into various media in Table S1.

\subsection{Pre-treatment of Anaerobic Digestate of Piggery Wastewater}

The raw piggery wastewater (PW) used in this study was obtained from storage tanks on a swine farm located in Yongin, Korea, which contained the mixture of feces, urine, and tap water that was used for cleaning pig pens. After arriving at the laboratory, the piggery wastewater was filtered through a $2 \mathrm{~mm}-\mathrm{mesh}$ to remove the coarse particles and then stored at $4^{\circ} \mathrm{C}$ until use. This filtered wastewater has been anaerobically digested at the organic loading rate of 2.51 $\mathrm{g} \mathrm{COD} / \mathrm{L} \cdot \mathrm{d}$ in a $30 \mathrm{~L}$ reactor for longer than $3 \mathrm{y}$.

Air stripping of raw PW and anaerobic digestate (AD) was conducted in a cylindrical $1.0 \mathrm{~L}$ reactor (ID $90 \mathrm{~mm} \times \mathrm{H} 200 \mathrm{~mm}$ ) with a working volume of $0.5 \mathrm{~L}$. The $\mathrm{pH}$ of the wastewater was adjusted to $\mathrm{pH} 10.0$ using $5 \mathrm{~N} \mathrm{NaOH}$ and added into the stripping reactor kept at $37^{\circ} \mathrm{C}$. Air was introduced directly into the liquid phase of the reactor via an aquatic air stone at the aeration rate of $1 \mathrm{~L} / \mathrm{min}$ for $12 \mathrm{~h}$. In order to compensate water loss during air stripping, distilled water was added up to the initial volume. Chlorination of wastewater was carried out with sodium hypochlorite $(\mathrm{NaOCl})$ at the dosage of $1.2 \mathrm{~g} / \mathrm{L}\left(\mathrm{Cl}: \mathrm{NH}_{3}-\mathrm{N}\right.$ mass ratio of 3.6:1) for $2 \mathrm{~h}$, and then chlorination reaction was immediately stopped 
by adding a stoichiometric amount of sodium sulfite $\left(\mathrm{Na}_{2} \mathrm{SO}_{3}\right)$.

These pre-treated wastewaters were re-adjusted to $\mathrm{pH} 7.6$ using $5 \mathrm{~N} \mathrm{HCl}$ and used for growing microalgal cells under the same culture conditions as above. Before inoculation, all media in Table S1 except BG-11 were 10-folds diluted with distilled water to reduce the toxic influence of ammonia on algal growth as Park et al. [4] did.

\subsection{Determination of Microalgal Growth}

For monitoring microalgal growth, optical density was measured at $680 \mathrm{~nm}$ every day using a spectrophotometer (Genesys 20, Thermo spectronic, Waltham, Massachusetts, USA). Number of microalgal cells was also counted microscopically using a Neubauer hemocytometer (INCYTO C-Chip, Korea). For measuring dry cell weight of algal biomass, $10 \mathrm{~mL}$ of culture were filtered through a mixed cellulose ester membrane filter $(0.2 \mu \mathrm{m}$, Advantec, Japan), rinsed with deionized water, dried in an oven at $105^{\circ} \mathrm{C}$ for $12 \mathrm{~h}$, cooled in a silica gel desiccator and then weighed. The relationship between optical density $(680 \mathrm{~nm})$ and dry cell weight appeared linear as in Eq. (1).

Dry cell weight $(\mathrm{g} / \mathrm{L})=0.42 \times \mathrm{OD}_{680}-0.13\left(\mathrm{R}^{2}=0.98\right)$

The specific growth rate $\left(\mu, \mathrm{d}^{-1}\right)$ in an exponential phase of algal growth was calculated by using Eq. (2);

$$
\mu=\left(\ln X_{2}-\ln X_{1}\right) /\left(t_{2}-t_{1}\right)
$$

where $X_{1}$ and $X_{2}$ were dry cell weights $(\mathrm{g} / \mathrm{L})$ at time $t_{1}$ and $t_{2}$, respectively. The biomass productivity $\left(P_{\text {biomass }}, \mathrm{g} / \mathrm{L} \cdot \mathrm{d}\right)$ was calculated according to Eq. (3);

$$
P_{\text {biomass }}=\left(X_{2}-X_{1}\right) /\left(t_{2}-t_{1}\right)
$$

The growth yield ( $Y_{X / S}$, dimensionless) was calculated using Eq. (4);

$$
Y_{\mathrm{X} / \mathrm{S}}=\left(X_{2}-X_{1}\right) /\left(S_{2}-S_{1}\right)
$$

where $X$ and $S$ were the dry cell weight $(\mathrm{g} / \mathrm{L})$ and concentration of total dissolved nitrogen $(\mathrm{TDN})(\mathrm{g} / \mathrm{L})$, respectively.

\subsection{Analytical Methods}

COD was analyzed using the HACH colorimetric method 8,000 and the DR/2,500 spectrophotometer (HACH, Loveland, Colorado, USA). TN and TP were analyzed based on the persulfate digestion method using HACH type HR total nitrogen Test ' $\mathrm{N}$ Tube ${ }^{\mathrm{TM}}$ vials and HACH type HR total phosphorus Test ' $\mathrm{N}$ Tube ${ }^{\mathrm{TM}}$ vials, respectively. Concentrations of ammoniacal nitrogen $\left(\mathrm{NH}_{3}-\mathrm{N}\right)$ and nitrate nitrogen $\left(\mathrm{NO}_{3}^{-}-\mathrm{N}\right)$ were measured by using $\mathrm{HACH}$ type HR ammonia Test ' $\mathrm{N}$ Tube ${ }^{\mathrm{TM}}$ vials and HACH type HR nitrate Test 'N Tube ${ }^{\mathrm{TM}}$ vials, respectively. True and apparent colors were measured following the Platinum-Cobalt Standard Methods (120 color, $455 \mathrm{~nm}$ ) [48]. Total solids (TS) were measured following the Standard Methods [49], and $\mathrm{pH}$ was measured using a $\mathrm{pH}$ meter (Orion star A211, Thermo spectronic, Waltham, Massachusetts, USA). For measuring soluble chemical oxygen demand (SCOD), TDN, and total dissolved phosphorous (TDP), samples were centri- fuged at 1,800 g for $10 \mathrm{~min}$, and the supernatants were filtered through $0.2 \mu \mathrm{m}$ membranes (Advantec, Japan). Measurements were carried out in triplicate and expressed as means \pm standard deviations (SD). Results of nutrient removal were statistically analyzed by one-way analysis of variance (ANOVA) and then by Tukey's post hoc analysis with significance level at $p<0.05$ using SPSS for Windows ver. 22.0 (IBM Corp., Armonk, New York, USA).

\section{Results and Discussion}

\subsection{Characteristics of Anaerobically-digested Piggery Wastewater and Algal Growth}

As shown in Table 1, strength of raw piggery wastewater was dramatically lowered after anaerobic digestion. Total COD (TCOD) and SCOD of raw PW decreased from $75.4 \mathrm{~g} / \mathrm{L}$ and $24.4 \mathrm{~g} / \mathrm{L}$ to 16.7 g/L (77.9\% reduction) and $6.1 \mathrm{~g} / \mathrm{L}$ (75.0\% reduction), respectively, in $\mathrm{AD}$. TN and TP were also reduced by anaerobic digestion from $5.9 \mathrm{~g} / \mathrm{L}$ to $4.0 \mathrm{~g} / \mathrm{L}$ (32.2\% reduction) and from 470 to $300 \mathrm{mg} / \mathrm{L}$ (36.2\% reduction), respectively. However, the $\mathrm{NH}_{3}-\mathrm{N}$, the main component of TN, decreased slightly from $3.95 \mathrm{~g} / \mathrm{L}$ to $3.70 \mathrm{~g} / \mathrm{L}$. TS also decreased a little from $59.6 \mathrm{~g} / \mathrm{L}$ to $53.4 \mathrm{~g} / \mathrm{L}$. Meanwhile color and $\mathrm{pH}$ obviously increased from 7,133 Pt-Co to 8,367 Pt-Co and from $\mathrm{pH} 7.6$ to $\mathrm{pH}$ 8.5, respectively. Dark brown color of PW changed to black after anaerobic digestion probably due to formation of iron sulfide (FeS) and humic substances derived from incomplete breakdown of lignin in PW [41]. Characteristics of pre-treated anaerobic digestate $(\mathrm{AD} C \mathrm{AD} S$, and $\mathrm{AD} M)$ will be discussed later.

C. vulgaris AG10032 growth as indicated by cell numbers in the BG-11 medium and 1-, 10-, 20- and 50-folds diluted anaerobic digestate of piggery wastewater $(\mathrm{AD})$ are shown in Fig. 1. Although COD was greatly reduced by anaerobic digestion, $C$. vulgaris did not grow at all in the undiluted $\mathrm{AD}(1 \mathrm{x}$ diluted $\mathrm{AD})$. This was thought to be due to high concentration of $\mathrm{NH}_{3}-\mathrm{N}$ in $\mathrm{AD}(3.7 \mathrm{~g} / \mathrm{L}$ of $\mathrm{NH}_{3}-\mathrm{N}$ ). Tam and Wong [50] observed a complete inhibition of growth of $C$. vulgaris in a commercial Bristol medium containing $750 \mathrm{mg} / \mathrm{L}$ of $\mathrm{NH}_{3}-\mathrm{N}$. Park et al. [4] also observed that growth of Scenedesmus sp. was completely inhibited in anaerobic digestate of piggery wastewater containing $1 \mathrm{~g} / \mathrm{L}$ of ammonium-nitrogen $\left(\mathrm{NH}_{4}{ }^{+}-\mathrm{N}\right)$. In case of 10 -folds diluted $\mathrm{AD}$ containing $400 \mathrm{mg} / \mathrm{L}$ of $\mathrm{NH}_{3}-\mathrm{N}$, the alga did not grow until $5.5 \mathrm{~d}$ of cultivation and started to grow slowly after $6 \mathrm{~d}$. For higher dilutions, the alga grew steadily in 20- and 50-folds diluted ADs (100-200 mg/L of $\left.\mathrm{NH}_{3}-\mathrm{N}\right)$ without noticeable lag phases. Similar results were also reported by Khanh et al. [29], Wang et al. [20] and Wang et al. [21] who observed algal growth in 20-folds diluted digestate (43-100 mg/L of $\left.\mathrm{NH}_{3}-\mathrm{N}\right)$. It was suspected that a high level of ammonia in $\mathrm{AD}$ delayed the growth of microalgal cells via the ammonia toxicity, high $\mathrm{pH}$, and the uncoupling effect on electron transport in photosystems [29]. A simple way to overcome the toxic effect of ammonia was to dilute anaerobic digestate as shown by this and other studies.

In addition to high concentrations of $\mathrm{NH}_{3}-\mathrm{N}$, dark color of $\mathrm{AD}$ was also thought to attribute to the poor growth of $C$. vulgaris. As shown in Table 1, a high level of TS (53 g/L) and the strong black color $(8,367 \mathrm{Pt}-\mathrm{Co})$ of non-diluted $\mathrm{AD}$ obviously reduced light penetration into the culture medium and thereby hindered 
Table 1. Characteristics of Various Wastewaters Used in This Study (mean \pm SD)

\begin{tabular}{|c|c|c|c|c|c|c|}
\hline & PW & PW_S & AD & AD_S & AD_C & AD_M \\
\hline $\mathrm{pH}$ & 7.63 & 9.49 & 8.49 & 9.48 & 7.63 & 7.63 \\
\hline TS (g/L) & $59.6 \pm 0.51$ & $56.7 \pm 0.78$ & $53.4 \pm 4.72$ & $40.1 \pm 2.29$ & $26.0 \pm 0.45$ & $19.5 \pm 0.1$ \\
\hline TCOD (g COD/L) & $75.4 \pm 0.1$ & $70.1 \pm 0.56$ & $16.7 \pm 0.15$ & $13.8 \pm 0.5$ & $8.9 \pm 0.32$ & $6.5 \pm 0.36$ \\
\hline SCOD (g COD/L) & $24.4 \pm 0.27$ & $19.9 \pm 0.36$ & $6.1 \pm 0.38$ & $5.9 \pm 0.27$ & $5.0 \pm 0.35$ & $4.3 \pm 0.2$ \\
\hline TN (g N/L) & $5.9 \pm 0.3$ & $2.2 \pm 0.1$ & $4.0 \pm 0.12$ & $2.0 \pm 0.15$ & $3.8 \pm 0.06$ & $1.4 \pm 0.2$ \\
\hline Ammoniacal-N (g NH$\left.{ }_{3}-\mathrm{N} / \mathrm{L}\right)$ & $3.95 \pm 0.03$ & $1.08 \pm 0.02$ & $3.7 \pm 0.06$ & $0.92 \pm 0.01$ & $3.0 \pm 0.03$ & $0.8 \pm 0.02$ \\
\hline Nitrate-N (g NO$\left.{ }_{3}-\mathrm{N} / \mathrm{L}\right)$ & $0.04 \pm 0.01$ & $0.04 \pm 0.00$ & $0.12 \pm 0.01$ & $0.12 \pm 0.00$ & $0.48 \pm 0.02$ & $0.49 \pm 0.02$ \\
\hline TP (g P/L) & $0.47 \pm 0.01$ & $0.44 \pm 0.00$ & $0.3 \pm 0.01$ & $0.29 \pm 0.01$ & $0.27 \pm 0.01$ & $0.29 \pm 0.01$ \\
\hline Color (Pt-Co) & $7,133 \pm 153$ & $4,067 \pm 231$ & $8,367 \pm 208$ & $7,767 \pm 306$ & $5,583 \pm 95$ & $4,400 \pm 458$ \\
\hline
\end{tabular}

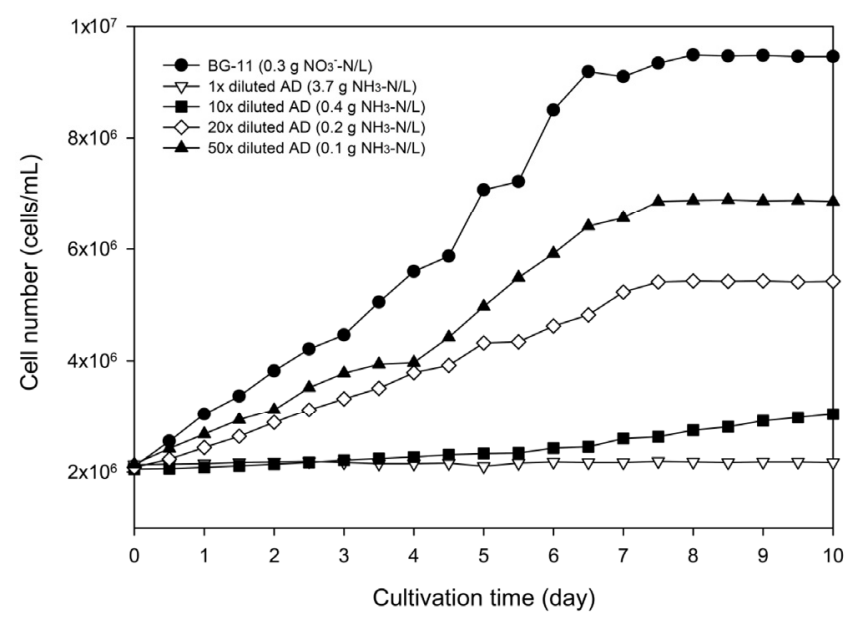

Fig. 1. Cell numbers of $C$. vulgaris grown in BG-11 and diluted anaerobic digestates (AD) of piggery wastewater.

microalgal growth [42, 51-52]. According to Moheimani et al. [41], the dark color lowed cellular productivity by $20-30 \%$ when compared to a non-colored culture medium. These results together showed that successful algal growth in diluted anaerobic digestate was thought to be brought by not only reduced ammonia toxicity but also improved light transmittance.

\subsection{Pre-treatment of Anaerobic Digestate for Ammonia and Color Removal}

In many studies on cultivation of microalgae in animal-manure wastewater, ammonia toxicity and light limitation were avoided by diluting the wastewater with clean water [5, 13, 34, 41-42], and Fig. 1 also confirmed this observation. However, the dilution method for large-scale systems would be unsustainable because a large volume of water is demanded [41-42]. Therefore, it was necessary in this study to lower the ammonia concentration and color intensity for minimizing dilution with water. In this context, air stripping, chlorination, and a combination of these two methods were adopted as pre-treatment methods for $\mathrm{AD}$.

As shown in Table 1 and Fig. 2, air stripping (AD_S) decreased concentrations of $\mathrm{TN}$ and $\mathrm{NH}_{3}-\mathrm{N}$ of $\mathrm{AD}$ from $4,000 \mathrm{mg} / \mathrm{L}$ to 2,000 $\mathrm{mg} / \mathrm{L}(50.0 \%$ removal) and from 3,700 mg/L to $920 \mathrm{mg} / \mathrm{L}(75.0 \%$ removal), respectively. Concentrations of TS and TCOD were also lowered from $53.4 \mathrm{~g} / \mathrm{L}$ to $40.1 \mathrm{~g} / \mathrm{L}$ (24.8\% removal) and from 16.7 to $13.8 \mathrm{~g} / \mathrm{L}$ (17.0\% removal), respectively, while intensity of color decreased slightly (from 8,367 Pt-Co to 7,767 Pt-Co). In case of NaOCl-treated AD (AD_C), removal efficiencies of TS, TCOD, and color were higher than those achieved by air stripping. Concentrations of TS and TCOD were reduced from $53.4 \mathrm{~g} / \mathrm{L}$ to $26.0 \mathrm{~g} / \mathrm{L}$ (51.1\% removal) and from 16.7 to $8.9 \mathrm{~g} / \mathrm{L}$ (46.4\% removal), respectively. Color intensity decreased from 8,367 Pt-Co to 5,583 Pt-Co. Contrary to anticipation, chlorination did not decrease TN and $\mathrm{NH}_{3}-\mathrm{N}$ much, i.e., from 4,000 mg TN/L to 3,800 mg TN/L and from 3,700 mg $\mathrm{NH}_{3}-\mathrm{N} / \mathrm{L}$ to $3,000 \mathrm{mg} \mathrm{NH}_{3}-\mathrm{N} / \mathrm{L}$. Interestingly, concentration of nitrate $\left(\mathrm{NO}_{3}-\mathrm{N}\right)$ increased four folds (Table 1). It has been known that chlorination converts ammonia to nitrogen gas, but some of nitrogen still remains as chloramine, nitrate, and nitrogen trichloride $\left(\mathrm{NCl}_{3}\right)$ [53]. Pressley et al. [53] also reported that about $10 \%$ of $\mathrm{NH}_{3}-\mathrm{N}$ was converted to nitrate at $\mathrm{pH} 8$ or higher. As summarized in Fig. 2, air stripping efficiently removed ammoniacal nitrogen in $\mathrm{AD}$ (75.0\%), but $\mathrm{NaOCl}$ did not (18.6\%) remove ammonia as much as air stripping did. However, NaOCl-treatment was more efficient for removing color (33.3\%) than air stripping (7.2\%). These results suggested that NaOCl-treatment might be applicable only when light penetration is a limiting factor for microalgae cultivation.

In case of the combined treatment of air stripping and NaOCl-treatment ( $\mathrm{AD} \_\mathrm{M}$ ), concentrations of $\mathrm{TN}, \mathrm{NH}_{3}-\mathrm{N}$, TS, TCOD, and color intensity were reduced to $1,400 \mathrm{mg} / \mathrm{L}$ (65.4\% removal), $800 \mathrm{mg} / \mathrm{L}$ (78.4\% removal), $19.5 \mathrm{~g} / \mathrm{L}$ (63.3\% removal), $6.5 \mathrm{~g} / \mathrm{L}(61.0 \%$ removal), and 4,400 Pt-Co (47.5\% removal), respectively. Meanwhile, the concentration of nitrate increased to $490 \mathrm{mg} / \mathrm{L}$. Concentration of TP did not decrease in all cases (AD_S, AD_C, and $\mathrm{AD}_{-} \mathrm{M}$ ). By the combined treatment of air stripping and $\mathrm{NaOCl}$ treatment, the removal efficiencies of TS, TCOD and color in AD_M were improved by $12.2 \%, 14.6 \%$ and $14.2 \%$ compared to $\mathrm{AD}_{-} \mathrm{C}$. TN removal efficiency was also improved by $15.8 \%$ compared to AD_S. However, in the case of ammoniacal nitrogen removal efficiency, $\mathrm{AD}$ _M was only $3 \%$ higher than $\mathrm{AD}$ S. Thus it was summarized that the combined treatment of air stripping and $\mathrm{NaOCl}$ treatment was somewhat effective for removing TS, TCOD, color and $\mathrm{TN}$, but the removal efficiency of ammoniacal nitrogen was not significantly improved. 


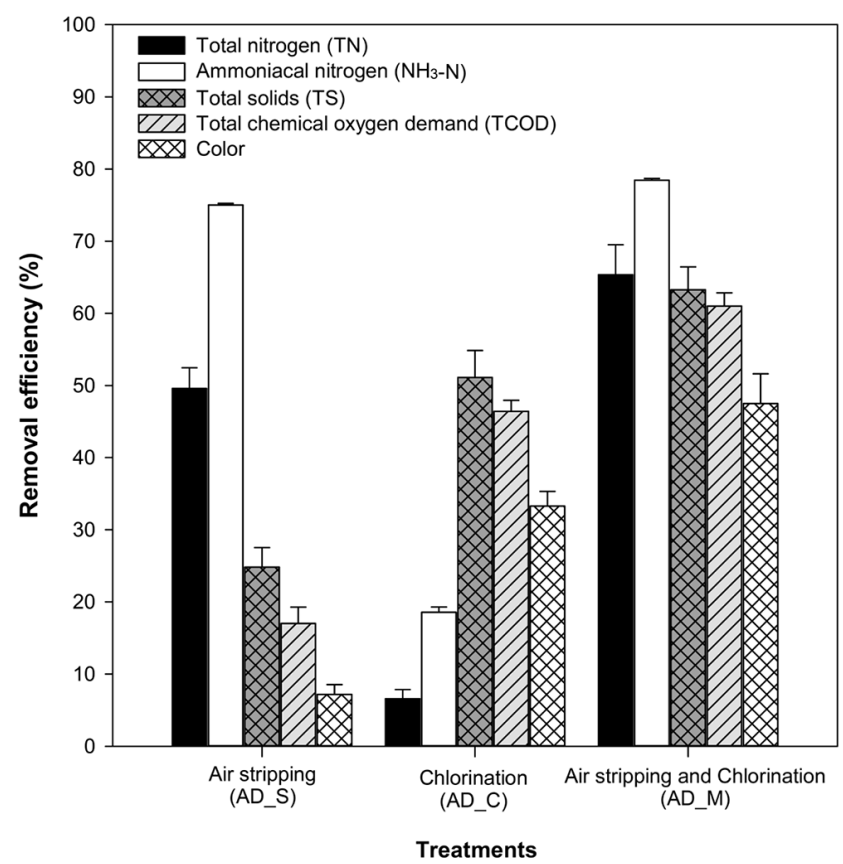

Fig. 2. Changes of characteristics of anaerobic digestate by air stripping, chlorination, and combined treatments (The error bars represent the standard deviation of three replicates).

\subsection{Assessment of Microalgal Growth}

C. vulgaris was grown in five different culture media for $14 \mathrm{~d}$ and growth parameters were estimated and summarized in Table 2. C. vulgaris showed slow or nearly no growth in the 10 -folds diluted $\mathrm{AD}$ and $\mathrm{AD} \_\mathrm{C}$ as also shown in Fig. 1. Specific growth rates $(\mu)$ of cultures in the 10 -folds diluted $\mathrm{AD}$ and $\mathrm{AD} C \mathrm{C}$ were only 0.026 and $0.004 \mathrm{~d}^{-1}$, respectively. Doubling times of $C$. vulgaris in $\mathrm{AD}$ and $\mathrm{AD} \_\mathrm{C}$ were longer than $26 \mathrm{~d}$. By contrast, $C$. vulgaris grew fast in 10-folds diluted $\mathrm{AD} \_\mathrm{S}$ and $\mathrm{AD}$ - $\mathrm{M}$ media, in which ammonia concentration was greatly reduced by air stripping. Concentrations of TDN and $\mathrm{NH}_{3}-\mathrm{N}$ in $\mathrm{AD} \_\mathrm{S}$ and $\mathrm{AD} \_\mathrm{M}$ were 102.7-103.3 mg TDN/L and 79.7-92.3 $\mathrm{mg} \mathrm{NH}_{3}-\mathrm{N} / \mathrm{L}$, respectively. Specific growth rates of $C$. vulgaris in $\mathrm{AD} \_\mathrm{S}$ and $\mathrm{AD} \_\mathrm{M}$ were 0.195 and $0.112 \mathrm{~d}^{-1}$, respectively. Thus doubling time in $\mathrm{AD} \_\mathrm{S}$ and $\mathrm{AD} \mathrm{M}$ were 3.56 and $6.19 \mathrm{~d}$, respectively. In particular, specific growth rate and doubling time of $C$. vulgaris grown in $\mathrm{AD}$ _S were equal or comparable to those grown in the BG-11 medium $\left(0.195 \mathrm{~d}^{-1}\right.$ and $3.55 \mathrm{~d})$. Surprisingly, even 10-folds diluted and air stripped PW (0.1x PW_S) supported growth of $C$. vulgaris (will be discussed further later). Meanwhile, $C$. vulgaris did not grow at all in the undiluted four different anaerobic digestates $\left(\mathrm{AD}, \mathrm{AD} \_\mathrm{S}, \mathrm{AD} \_\mathrm{C}\right.$, AD_M) (data not shown).

The maximum biomass concentration $\left(\mathrm{X}_{\max }\right)$ and biomass productivity ( $\left.P_{\text {biomass }}\right)$ of $C$. vulgaris grown in the BG-11 medium were $0.35 \mathrm{~g} / \mathrm{L}$ and $0.05 \mathrm{~g} / \mathrm{L} \cdot \mathrm{d}$, respectively. Those obtained in 10-folds diluted AD_S were the highest, reaching $1.51 \mathrm{~g} / \mathrm{L}$ and $0.22 \mathrm{~g} / \mathrm{L} \cdot \mathrm{d}$. Although $C$. vulgaris survived in 10-fold diluted $\mathrm{AD}$, the biomass concentration and biomass productivity of $C$. vulgaris were markedly lower than those in the ammonia-stripped media (AD_S and $\mathrm{AD}$ _M). Again culture in $\mathrm{AD}$ C showed the lowest biomass concentration $(0.02 \mathrm{~g} / \mathrm{L})$ and biomass productivity $(0.003 \mathrm{~g} / \mathrm{L} \cdot \mathrm{d})$ because ammonia concentration was still high (Table 1). The biomass productivity in $\mathrm{AD} \_\mathrm{S}$ was a little lower than that of Zhu et al. [5], who achieved $0.296 \mathrm{~g} / \mathrm{L} \cdot \mathrm{d}$ when they cultivated Chlorella zofingiensis in the autoclaved 1.8-folds-diluted piggery wastewater (1,900 mg/L of COD, $80 \mathrm{mg} / \mathrm{L}$ of TN, and $85 \mathrm{mg} / \mathrm{L}$ of TP). A similar $P_{\text {biomass }}$ was also reported by Cheng et al. [40], who achieved 0.22 $\mathrm{g} / \mathrm{L} \cdot \mathrm{d}$ for Desmodesmus sp. CHX1 cultivated in air-stripped and autoclaved piggery wastewater $(1,800 \mathrm{mg} / \mathrm{L}$ of COD, $100 \mathrm{mg} / \mathrm{L}$ of $\mathrm{TN}$, and $7.5 \mathrm{mg} / \mathrm{L} \mathrm{TP}$ ). Therefore, it was suspected that ammonia removal was essential not only for enhancing biomass productivity of $C$. vulgaris in anaerobically-digested piggery wastewater but also for cultivating other microalgal species in other ammonia-rich wastewaters. The growth yield coefficients $(Y)$ ranged from 1.59 to $24.22 \mathrm{mg} / \mathrm{mg}$ (Table 2). High yields were found in AD_S (24.22 $\mathrm{mg} / \mathrm{mg}$ ) and AD_M (13.22 mg/mg). Ji et al. [1] reported that growth yield of Scenedesmus obliquus was $6.7-7.1 \mathrm{mg} / \mathrm{mg}$ in diluted-piggery wastewater containing $280-961 \mathrm{mg} / \mathrm{L}$ of $\mathrm{NH}_{3}-\mathrm{N}$. In case of 10 -fold diluted $\mathrm{AD}$ and $\mathrm{AD} \_\mathrm{C}$, very low growth yields were obtained at 1.59 and $3.49 \mathrm{mg} / \mathrm{mg}$, respectively. This retarded algal growth in $\mathrm{AD}$ and $\mathrm{AD} \_\mathrm{C}$ was attributed to the high concentration of ammonia (> $300 \mathrm{mg} / \mathrm{L}$ of $\mathrm{NH}_{3}-\mathrm{N}$ ). This observation confirmed that the ammonia concentration was a critical parameter rather than color intensity

Table 2. Growth Parameters of C. vulgaris Grown in Five Different Culture Media

\begin{tabular}{|c|c|c|c|c|c|}
\hline Medium $^{a}$ & $\begin{array}{l}\text { Specific growth rate } \\
\qquad\left(\mu, d^{-1}\right)^{b}\end{array}$ & $\begin{array}{l}\text { Doubling time } \\
\qquad\left(t_{d}, d\right)^{b}\end{array}$ & $\begin{array}{l}\text { Maximum biomass concentration } \\
\qquad\left(X_{\max }, g / L\right)^{c}\end{array}$ & $\begin{array}{l}\text { Biomass productivity } \\
\left(P_{\text {biomass }}, \mathrm{g} / \mathrm{L} \cdot \mathrm{d}\right)^{\mathrm{b}}\end{array}$ & $\begin{array}{l}\text { Growth yield } \\
(Y, \mathrm{mg} / \mathrm{mg})^{\mathrm{d}}\end{array}$ \\
\hline $0.1 \times$ PW_S & 0.204 & 3.40 & 3.98 & 0.57 & 37.67 \\
\hline BG-11 & 0.195 & 3.55 & 0.35 & 0.05 & 3.03 \\
\hline $0.1 \times \mathrm{AD}$ & 0.026 & 26.36 & 0.32 & 0.03 & 1.59 \\
\hline $0.1 \times$ AD_C & 0.004 & 189 & 0.02 & 0.003 & 3.49 \\
\hline $0.1 \times$ AD_S & 0.195 & 3.56 & 1.52 & 0.22 & 24.22 \\
\hline $0.1 \times \mathrm{AD}_{-} \mathrm{M}$ & 0.112 & 6.19 & 0.93 & 0.07 & 13.22 \\
\hline
\end{tabular}

${ }^{a}$ Media were 10 -fold diluted $(0.1 \mathrm{x})$ except BG-11.

${ }^{\mathrm{b}}$ Specific growth rate, doubling time, and biomass productivity were calculated in terms of dry cell weight at $7 \mathrm{~d}$ cultivation.

${ }^{\mathrm{C}}$ Maximun biomass productions were measured over $14 \mathrm{~d}$ of cultivation.

${ }^{\mathrm{d}}$ Growth yields were calculated based on TDN uptake for $14 \mathrm{~d}$ of cultivation. 
for determining growth of $C$. vulgaris.

Markou et al. [43] treated olive-oil mill wastewater with sodium hypochlorite ( $\mathrm{NaOCl}$ ) for phenol and color removal, by which biomass productivity of Arthrospira was enhanced. However, Zhu et al. [34] reported that cultivation of $C$. zofingiensis in NaOCl-treated piggery wastewater did not enhance nutrient removal, algal growth and biodiesel production. In this study, $C$. vulgaris grown in NaOCl-treated anaerobic digestate (AD_C) also showed the lowest specific growth rate and biomass productivity. One possible reason for the poor growth of $C$. vulgaris might be high levels of inorganic nitrogen species including ammonia $(300 \mathrm{mg} / \mathrm{L}$ of $\mathrm{NH}_{3}-\mathrm{N}$ ) and nitrate $\left(48 \mathrm{mg} / \mathrm{L}\right.$ of $\left.\mathrm{NO}_{3}{ }^{-} \mathrm{N}\right)$. Another reason could be found in inhibitory effects of chlorinated disinfection by-products (DBPs). Liang et al. [54] suspected that formation of DBPs from chlorination of organic pollutants might be responsible for the growth inhibition of Chlorella pyrenoidosa. Yang et al. [55] also observed the toxicological effect of halogenated DBPs in the chlorinated wastewater effluent against growth of marine alga Tetraselmis marina.

Biomass productivities of 10 -fold diluted PW_S, AD_S and $\mathrm{AD}$ _M, all of which were air stripped, were 11.4 times, 4.4 times and 1.4 times higher than that of BG-11, respectively. On the other hand, biomass productivity decreased in 10-fold diluted $\mathrm{AD}$ C possibly due to toxicity of chlorinated disinfection by-products. Therefore, it was decided to apply air stripping for pre-treating $\mathrm{AD}$ rather than $\mathrm{NaOCl}$-treatment.

\subsection{Effect of SCOD Concentration on Growth of $C$. Vulgaris}

Since $C$. vulgaris grew very slowly even in 10-folds diluted $\mathrm{AD}$ (Fig. 1 and Table 2), it was not expected at all at first that $C$. vulgaris might grow in raw piggery wastewater. However air stripping appeared very effective to remove ammonia and enable $C$. vulgaris to grow in high-strength wastewater. Thus, 10-fold diluted raw piggery wastewater was air-stripped under the same conditions as in $\mathrm{AD} S$ and $\mathrm{AD} \mathrm{M}$ to examine if $C$. vulgaris grew. SCOD and $\mathrm{NH}_{3}-\mathrm{N}$ concentrations in this 10-fold diluted ammonia-stripped piggery wastewater (0.1x PW_S) were 2,000 mg/L and $108 \mathrm{mg} / \mathrm{L}$ (refer to Table 1), respectively, which was higher than $0.1 \mathrm{x}$ AD_S and 0.1x AD_M (400-600 mg/L of SCOD and 80-92 mg/L of $\left.\mathrm{NH}_{3}-\mathrm{N}\right)$. On the other hand, color levels of 10-fold diluted PW S (400 Pt-Co) was lower than 0.1x AD S and 0.1x AD M (440-780 Pt-Co). Surprisingly, cultivation of $C$. vulgaris in 10 -fold diluted PW_S for $14 \mathrm{~d}$ resulted in high nutrient removal efficiencies of $99.8 \%$ for $\mathrm{NH}_{3}-\mathrm{N}, 76.9 \%$ for TDN, $62.5 \%$ for TDP, and $81.9 \%$ for SCOD (data not shown), high specific growth rate $\left(0.20 \mathrm{~d}^{-1}\right)$, high biomass productivity $(0.57 \mathrm{~g} / \mathrm{L} \cdot \mathrm{d})$, and high growth yield $(37.67 \mathrm{mg} / \mathrm{mg})$ (Table 2). Again as summarized in Table 2, the biomass productivities ( $\left.P_{\text {biomass }}\right)$ of the 10 -fold diluted ammonia-stripped wastewaters (0.1x PW_S, 0.1x AD_S, and 0.1x AD_M) were much higher than that of $\overline{B G}-11$.

Moreover, it was found that $P_{\text {biomass }}$ was linearly correlated with the initial SCOD concentration $\left(\mathrm{R}^{2}=0.97\right)$. As shown in Fig. 3, initial SCOD concentrations of BG-11, 0.1x AD_M, 0.1x AD_S, and 0.1x PW_S were $0.3 \mathrm{~g} / \mathrm{L}, 0.43 \mathrm{~g} / \mathrm{L}, 0.59 \mathrm{~g} / \mathrm{L}$ and $1.99 \mathrm{~g} / \mathrm{L}$, respectively, and $P_{\text {biomass }}$ were $0.05 \mathrm{~g} / \mathrm{L} \cdot \mathrm{d}, 0.07 \mathrm{~g} / \mathrm{L} \cdot \mathrm{d}, 0.22 \mathrm{~g} / \mathrm{L} \cdot \mathrm{d}, 0.57$ $\mathrm{g} / \mathrm{L} \cdot \mathrm{d}$, respectively. The growth yield $(Y)$ was also well correlated with the log of initial SCOD concentration $\left(\mathrm{R}^{2}=0.95\right)$. Accordingly, $Y$ was obviously well correlated with $P_{\text {biomass }}\left(\mathrm{R}^{2}=0.97\right.$, data not shown). Li et al. [19] reported that when Chlorella sp. was grown in autoclaved (initial concentration of 2,390 mg COD/L) and raw (initial concentration of 2,304 mg COD/L) wastewaters, the removal efficiency of COD were $90.3 \%$ and $90.8 \%$, respectively. Li et al. [19] also reported that, in the presence of high COD in the wastewater, the microalgal growth was vigorous without a lag phase. These results suggested that a high concentration of COD might enhance the growth of $C$. vulgaris and correspondingly nutrients removal if ammonia concentration was appropriately adjusted. Previous studies have reported that some Chlorella sp. are mixotrophic so that $\mathrm{CO}_{2}$ and organic carbon could be used simultaneously [56-57]. Especially, Martinez et al. [56] found that the C. pyrenoidosa completely consumed the organic substrates when cultured under a weak light condtion ( 1,500 Lux). Lalucat et al. [57] also reported that Chlorella sp. grew heterotrophically by utilizing various organic compounds.

The $P_{\text {biomass }}$ in 10-fold diluted PW_S, $0.57 \mathrm{~g} / \mathrm{L} \cdot \mathrm{d}$, was higher than that $0.222 \mathrm{~g} / \mathrm{L} \cdot \mathrm{d}$ of a previous report of Cheng et al. [40] that was obtained from cultivation of Desmodesmus sp. CHX1 in ammonia-stripped piggery wastewater. Furthermore, when they supplemented $\mathrm{CO}_{2}$ in the same media, $P_{\text {biomass }}$ increased to $0.869 \mathrm{~g} / \mathrm{L} \cdot \mathrm{d}$. Cheng et al. [40] and Kim et al. [36] reported that microalgal biomass concentration, productivity, and specific growth rate increased in the presence of $\mathrm{CO}_{2}$. These results indicated that $\mathrm{CO}_{2}$ supplementation could enhance microalgal growth and biomass productivity in ammonia-stripped raw and anaerobically-digestated piggery wastewater. The biomass productivities of $0.1 \mathrm{x} \mathrm{AD} \_\mathrm{S}$ and $0.1 \mathrm{x}$ $\mathrm{AD}$ _M, which contained high concentrations of organic matters were 4.4 and 1.4 times, respectively, higher than that of a mineral medium, BG-11.

In the presence of light and organic matters, $C$. vulgaris is known to convert to mixotrophic growth consuming both organic matters and $\mathrm{CO}_{2}$ [56-60]. According to Li et al. [60] and Liang et al. [61], the $\mathrm{C} / \mathrm{N}$ ratio affected the mixotrophic growth and lipid content of $C$. vulgaris. Other researchers also reported that the optimal C/N ratio was 5-15 for cultivating $C$. vulgaris mixotrophically [57-58]. Based on well-known microalgal cell composition $\left(\mathrm{C}_{1.06} \mathrm{H}_{1.81} \mathrm{O}_{0.45}\right.$ $\mathrm{N}_{0.16} \mathrm{P}_{0.01}$ ) [62], the $\mathrm{C} / \mathrm{N}$ molar ratio is 6.6 (mass ratio of 8.9 ), and sufficient carbon and nitrogen are required for vigorous growth. In this study, the initial $\mathrm{C} / \mathrm{N}$ ratios were different for different wastewaters and the pre-treatment methods. As shown in Fig. 4, the initial $\mathrm{C} / \mathrm{N}$ ratios (i.e., SCOD/TDN ratios) of $0.1 \mathrm{x}$ PW_S, $0.1 \mathrm{x}$ $\mathrm{AD}, 0.1 \mathrm{x}$ AD_S, 0.1x AD_C and 0.1x AD_M were 14.53, 1.79, 5.73, 1.56 and 4.17 , respectively. $\mathrm{C} / \mathrm{N}$ ratios of both $0.1 \mathrm{x}$ PW_S and $0.1 \mathrm{x}$ AD_S were in the optimal $\mathrm{C} / \mathrm{N}$ ratio range and showed higher specific growth rates $\left(0.204\right.$ and $0.195 \mathrm{~d}^{-1}$, respectively) than the other pre-treatments (0.004-0.112 $\left.\mathrm{d}^{-1}\right)$ (Table 2). Although the chlorination method was commonly used, $\mathrm{AD} \_\mathrm{M}$ with a high $\mathrm{C} / \mathrm{N}$ ratio showed a specific growth rate about 28 times higher than that of $\mathrm{AD} C$. On the other hand, poor growth were observed in $0.1 \mathrm{x}$ $\mathrm{AD}$ and $0.1 \mathrm{x} \mathrm{AD} C$ with low $\mathrm{C} / \mathrm{N}$ ratios. The characteristics of PW_S and AD_S (also 0.1x PW_S and 0.1x AD_S) were not significantly different except for COD, color and TP (Table 1 and Fig. 4). However, specific growth rate, maximum biomass concen- 
tration, biomass productivity and growth yield of $C$. vulgaris grown in 0.1x PW_S were 1.05, 2.62, 2.59 and 1.56 times higher than those obtained in $0.1 \mathrm{x}$ AD_S, respectively. These results suggested that mixotrophic growth of $C$. vulgaris was dependent on not only $\mathrm{C} / \mathrm{N}$ ratios but also refractory organic matters. According to Zeng et al. [63], a high proportion of refractory organic matters were found after anaerobic digestion of piggery wastewater. Thus, when microalgae were subjected to mixotrophic growth, 0.1x PW_S containing high levels of easily-biodegradable organic seemed to support stronger growth than $\mathrm{AD}$ S.

Thus, it was clear that mixotrophic microalgal cells could be cultured in a medium containing a high concentration of organic matters if ammoniacal nitrogen concentration is reduced to an uninhibitory level and suitable $\mathrm{C} / \mathrm{N}$ ratio.

To summarize, $C$. vulgaris used in the present study grew without any sign of inhibition in the 10-folds diluted air-stripped PW (PW_S) containing initial concentrations of 2,000 mg SCOD/L, $220 \mathrm{mg} \mathrm{TN} / \mathrm{L}$ (137 mg TDN/L), $100 \mathrm{mg} \mathrm{NH}-\mathrm{N} / \mathrm{L}, 40 \mathrm{mg}$ TP/L (15 mg TDP/L) (Tables 1 and 2). These results were similar to Zhu et al. [5], who also investigated the growth of Chlorella sp. under the controlled conditions. They reported that the diluted piggery wastewater containing 1,900 mg/L COD, $80 \mathrm{mg} / \mathrm{L} \mathrm{TN}$ and $85 \mathrm{mg} / \mathrm{L} \mathrm{TP}$ provided optimal conditions for $C$. zofingiensis cultivation. Chen et al. [30] also reported that the optimal growth rate of Chlorella sp. was obtained in an anaerobic digestate containing $200 \mathrm{mg} / \mathrm{L}$ TN and $2.5 \mathrm{mg} / \mathrm{L}$ TDP. Although high strength-wastewater contained organic matters, the biomass productivity of $0.1 \mathrm{x}$ PW_S was 2.5 times higher than Cheng et al. [40] and the results of 10-fold diluted AD_S was similar to those of a previous study [40]. Thus it was reasonable to conclude that air stripping was an effective method for culturing microalgae in the raw and anaerobically-digested piggery wastewaters.

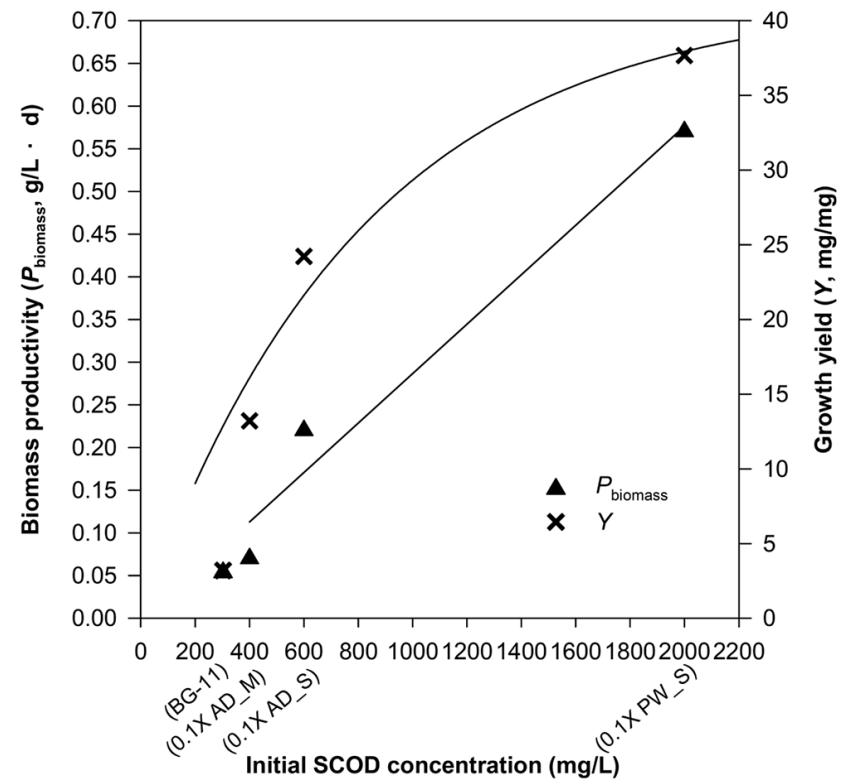

Fig. 3. Effects of initial SCOD concentration on biomass productivity $\left(P_{\text {biomass }}\right)$ and growth yield $(\mathrm{Y})$ of $\mathrm{C}$. vulgaris grown in BG-11 medium and 10-folds diluted AD_M, AD_S, and PW_S.

\subsection{Nutrient Removal by $C$. vulgaris}

Fig. 4 shows $\mathrm{NH}_{3}-\mathrm{N}$, TDN, TDP, and SCOD removal by $C$. vulgaris grown for $14 \mathrm{~d}$ in 10-folds diluted PW S, AD, $\mathrm{AD}$ C, $\mathrm{AD} \mathrm{S}$, and AD_M. Nutrient uptake of $C$. vulgaris appeared clearly different according to pre-treatment methods (air stripping and NaOCl-treatment). The culture in $0.1 \mathrm{x} \mathrm{AD} \_\mathrm{C}$ showed the lowest nutrient removal efficiency ( $p<0.05$ ), because $C$. vulgaris did not grow well in this medium (Table 2). The culture in air-stripped media $(0.1 \mathrm{x}$ PW_S, 0.1x AD_S and 0.1x AD_M) showed the high $\mathrm{NH}_{3}-\mathrm{N}$ removal efficiencies of 98.7-99.8\% ( $p<0.05)$. The concentrations of $\mathrm{NH}_{3}-\mathrm{N}$ decreased from $108.0 \pm 2.0$ to $0.2 \pm 0.2 \mathrm{mg} / \mathrm{L}$ in $0.1 \mathrm{x}$ PW_S, from $92.3 \pm 0.6$ to $1.2 \pm 0.4 \mathrm{mg} / \mathrm{L}$ in $0.1 \mathrm{x} \mathrm{AD \_ S}$ and from $79.7 \pm 1.5$ to $0.6 \pm 0.1 \mathrm{mg} / \mathrm{L}$ in $0.1 \mathrm{x}$ AD_M. The removal efficiency of TDN was also high in 0.1x PW_S and 0.1x AD_M $(p<0.05)$. As shown in Fig. 4(b), concentrations of TDN decreased from 137.3 \pm 1.5 to $31.7 \pm 4.9 \mathrm{mg} / \mathrm{L}$ in $0.1 \mathrm{x}$ PW_S (76.9\% uptake) and from 102.7 \pm 2.1 to $32.3 \pm 0.6 \mathrm{mg} / \mathrm{L}$ in $0.1 \mathrm{x}$ AD_M (68.5\% uptake). Similar results were reported by Wang et al. [35], who found that $C$. pyrenoidosa cultivated in 10-, 15-, 20-, and 40-folds diluted piggery wastewater (34.7-138.8 mg/L of initial $\mathrm{NH}_{3}-\mathrm{N}$ concentration) showed removal efficiencies of 91.2-95.1\% for $\mathrm{NH}_{3}-\mathrm{N}, 54.7-74.6 \%$ for $\mathrm{TN}$, and $31.0-77.7 \%$ for TP. Kumar et al. [64] also reported that the maximum $\mathrm{NH}_{3}-\mathrm{N}$ reduction by $C$. vulgaris was $61.8 \%$ in 50 -folds diluted anaerobic digestate of piggery wastewater containing $20 \mathrm{mg} / \mathrm{L}$ of initial $\mathrm{NH}_{3}-\mathrm{N}$. C. vulgaris grown in $0.1 \mathrm{x}$ PW_S and $0.1 \mathrm{x}$ AD_S removed $62.5 \%$ and $58.9 \%$ of TDP, respectively. From these final concentrations, it seems to be possible to satisfy the effluent limitation guidelines for livestock excreta in Korea $(60 \mathrm{mg} / \mathrm{L}$ of TN and $8 \mathrm{mg} / \mathrm{L}$ of TP) [65] by combining air stripping and algal cultivation. The removal efficiencies of SCOD in 0.1x PW_S, 0.1x AD, 0.1x AD_C, 0.1x AD_S and 0.1x AD_M were 81.9\% (residual concentration (RC): $360 \mathrm{mg} / \mathrm{L}$ ), 58.3\% (RC: $255 \mathrm{mg} / \mathrm{L}$ ), $47.0 \%$ (RC: $265 \mathrm{mg} / \mathrm{L}$ ), 59.2\% (RC: $240 \mathrm{mg} / \mathrm{L}$ ) and 53.6\% (RC: $199 \mathrm{mg} / \mathrm{L})$ (Fig. 4(d)). Thus it was obvious that microalgal culture removed not only nitrogen and phosphorus but also dissolved organic matters at the same time.

Closely examining the experimental data of Table 2 and Fig. 4 , it was suspected that microalgal growth and concomitant nutrient removal might be affected by initial concentration of nitrogen or $\mathrm{N} / \mathrm{P}$ ratio in the wastewater. To investigate the effect of initial nitrogen concentration on the removal efficiency of nitrogen and phosphorus, the concentrations of $\mathrm{TN}$ and $\mathrm{TP}$ in various wastewaters and removal efficiencies were surveyed and summarized in Table 3. Microalgae were used to treat municipal wastewater $[15,23$, $66]$, industrial wastewater [67-68], piggery wastewater [5, 33, 69], anaerobic digestate [69-70] and synthetic wastewater [13, 71-72]. Commonly-used microalgae were $C$. vulgaris [13, 73], $C$. emersonii [22], C. pyrenoidosa [67], Chlorella sp. [70], Scenedesmus obliquus [15, 74], Scenedesmus sp. [25], etc. In some studies, naturally-borne microalgae [75] or more than two species of microalgae [76-77] were used for wastewater treatments. The initial concentrations of nitrogen and phosphorus ranged from 2.5 to $410 \mathrm{mg} / \mathrm{L}$ and from 2.1 to $199 \mathrm{mg} / \mathrm{L}$, respectively. For these initial concentrations of nutrients, the removal efficiencies of nitrogen and phosphorus were 2.5-100\% and 6.0-100\%, respectively. Different illumination intensity, initial concentration of nutrients and molar ratio of N/P seemed to result in different removal efficiencies. 

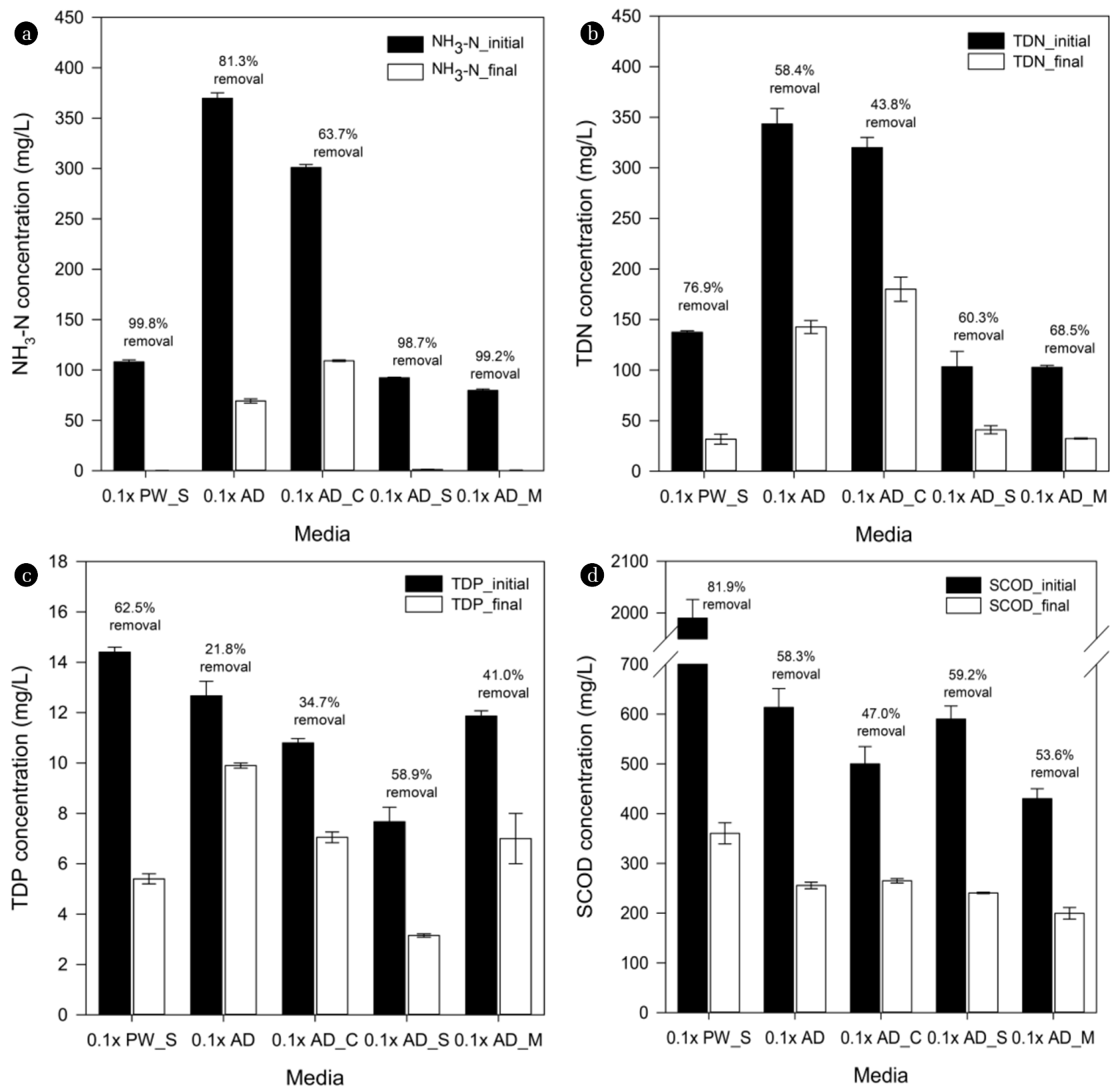

Fig. 4. The removal of (a) $\mathrm{NH}_{3}-\mathrm{N}$, (b) TDN, (c) TDP, and (d) SCOD by C. vulgaris grown for $14 \mathrm{~d}$ in 10-folds diluted (0.1x) wastewaters. The error bars represent the standard deviation of three replicates.

Fig. 5 that was drawn using data of Table S3 and Fig. 4 shows correlation between the removal efficiencies of TN and TP, and the initial concentration of TN. Regardless of wastewater characteristics, light intensity, temperature and microalgal species, the removal efficiencies of TN and TP appeared to decrease when the initial concentration of TN was higher than $100 \mathrm{mg} / \mathrm{L}$. When the initial concentration of $\mathrm{TN}$ is was lower $100 \mathrm{mg} / \mathrm{L}$, the removal efficiency seemed to be determined by various factors of the illumination intensity, the growth of microalgae species, the consumption rate of nitrogen and the presence of inhibitors in wastewater. One of the reasons why the high initial TN concentration lowered re- moval of TN and TP might be the negative effect of free ammonia $\left(\mathrm{NH}_{3}\right)$ on microbial metabolism. It is known that free ammonia easily diffuses into cells of microorganisms because of lipophilicity [78] and then converted to ammonium ions in the cell for satisfying the equilibrium constant [79]. For forming ammonium ions from ammonia inside the cells, hydrogen ions are pumped from outside, causing cation imbalance in the cells. Therefore, microorganisms undergo potassium reversal, in which potassium ions move out of cells [80-81]. In this biochemical process, the cellular energy is continuously consumed for maintaining an ionic equilibrium in the cell, which exerts a negative effect on the microorganisms 

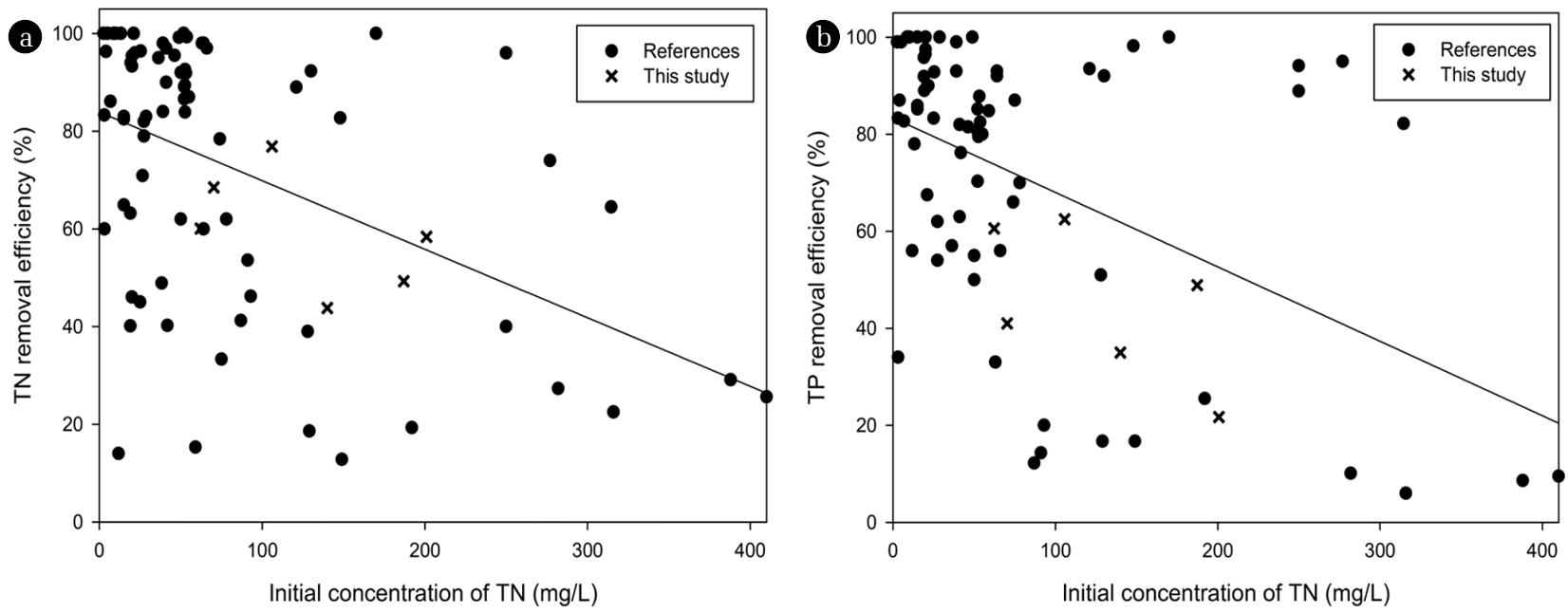

Fig. 5. TN and TP removal efficiencies by microalgal cultivation in various wastewaters (data were taken from Table S3 and Fig. 4).

Table 3. The TDN and TDP Removal by C. vulgaris in Five Different Media ${ }^{a}$

\begin{tabular}{|c|c|c|c|c|c|}
\hline \multirow{2}{*}{ Media } & \multicolumn{2}{|c|}{ TDN removed } & \multicolumn{2}{|c|}{ TDP removed } & \multirow{2}{*}{$\begin{array}{c}\text { Consumed } \\
\text { TDN/TDP ratio }\end{array}$} \\
\hline & Conc. (mg/L) & Removal ratio (\%) & Conc. (mg/L) & Removal ratio (\%) & \\
\hline $0.1 \times$ PW_S & $105.7 \pm 4.0$ & 76.9 & $9.0 \pm 0.4$ & 62.5 & 11.74 \\
\hline $0.1 \times \mathrm{AD}$ & $200.7 \pm 9.0$ & 58.4 & $2.8 \pm 0.6$ & 21.8 & 71.68 \\
\hline $0.1 \times$ AD_C & $140.0 \pm 2.0$ & 43.8 & $3.8 \pm 0$ & 35.0 & 36.84 \\
\hline $0.1 \times$ AD_S & $62.3 \pm 11.4$ & 60.1 & $4.9 \pm 0.1$ & 60.6 & 12.71 \\
\hline $0.1 \times$ AD_M & $70.3 \pm 1.5$ & 68.5 & $4.9 \pm 0.8$ & 41.0 & 14.35 \\
\hline
\end{tabular}

${ }^{a}$ Media were 10-fold diluted, and data were acquired from Fig. 4

on growth [78]. It is also known that accumulated intracellular ammonium ions inhibit the microbial growth because protein synthesis is hindered [82].

The N/P ratio may also affect microalgal growth. Microalgal cells $\left(\mathrm{C}_{1.06} \mathrm{H}_{1.81} \mathrm{O}_{0.45} \mathrm{~N}_{0.16} \mathrm{P}_{0.01}\right)$ undergoing phototrophic growth need nitrogen and phosphorus at the N/P molar ratio of 16:1 (mass ratio of 7.2:1) [62]. For cultivating freshwater microalgae (i.e., Chlorella sp. and Scenedesmus sp.), Wang et al. [35] and Li et al. [19] reported that the optimal N/P ratio was 5-10. Table 3 (data extracted from Fig. 4) shows the removed TDN and TDP concentrations and their TDN/TDP ratios obtained for 14-d of $C$. vulgaris cultivation. The mass ratios of consumed TDN to TDP in $0.1 \mathrm{x} \mathrm{AD}$ and $0.1 \mathrm{x}$ AD_C were 71.68 and 36.84, respectively, which were much higher than the mass ratio of 7.2:1 obtained by Redfield [62]. Chen et al. [31] observed similar ratios from freshwater algal cultivation in anaerobically-digested manure (72.2-76.9 of consumed N/P ratio). However, it should be noted that $C$. vulgaris did not grow well in $\mathrm{AD}$ and $\mathrm{AD} \_\mathrm{C}$ (Table 2). These results indicated that $\mathrm{AD}$ and $\mathrm{AD} \_\mathrm{C}$ contained excessive nitrogen (phosphorus limitation) and their N/P ratios were much higher than optimal ratio for this strain. Wang et al. [83] found that the consumed N/P ratios by Oedogonium sp. grown in digested piggery wastewater varied from 4.4 to 16.0. Wang et al. [21] also reported that Chlorella sp. showed consumed N/P ratios of 7.5-9.5 when grown in a growth media supplemented with digested diary wastewater. Taking a close look at the air-strip- ped three different media, it was noticed that PW_S, AD_S and $\mathrm{AD} \_\mathrm{M}$ supported active growth of $C$. vulgaris (Table 2) and removal of TDN and TDP (Fig. 4) at close-to-optimal ratios of 11.7-14.4 (Table 3). In short, compared to the untreated and chlorinated anaerobic digestate $\left(\mathrm{AD}\right.$ and $\left.\mathrm{AD} \_\mathrm{C}\right)$, ammonia-reduced (PW_S, $\mathrm{AD}$ _S , and AD_M) wastewaters provided favourable conditions for the growth of $C$. vulgaris. Aslan and Kapdan [13] suggested that the optimized N/P ratios enhanced the nutrient removal capability of $C$. vulgaris at high $\mathrm{N}$ and $\mathrm{P}$ concentrations.

The high concentrations of ammonia exert negative effects on microalgal growth and nutrient removal via two mechanisms. First, as discussed above, ammonia diffuses into the cell, and then cell continuously consumes cellular energy to maintain intracellular equilibria. Second, the inadequate molar ratio of $\mathrm{N} / \mathrm{P}$ may also lower cell growth and nutrient removal. The results in the present study and previous studies [13] showed that the nutrients removal was enhanced when the $\mathrm{N} / \mathrm{P}$ ratio was adjusted to the optimal ratio. Therefore, if ammonia is removed through air stripping, N/P ratio need to be re-adjusted.

\section{Conclusions}

The raw and anaerobically-digested piggery wastewaters containing nutrients and trace elements are promising microalgal culture 
media. Due to high ammoniacal nitrogen and various inhibitors, however, growth rate and removal efficiency of nutrients by microalgae in these wastewaters are known to be inhibited. Thus previous many studies have reduced the concentrations of nutrients and inhibitors by highly diluting the wastewater with water. In this study, air stripping, $\mathrm{NaOCl}$ treatment, and the combined treatment of both methods were applied to grow microalgae in minimally-diluted raw and anaerobically-digested PWs. When raw and anaerobically-digested piggery wastewaters were air-stripped and 10-folds diluted, microalgal cultivation in these media reduced ammoniacal nitrogen concentration from 2,000-3,700 $\mathrm{mg} / \mathrm{L}$ to 0.2-1.2 $\mathrm{mg} / \mathrm{L}$ and, as a result, biomass productivity $(0.22-0.57 \mathrm{~g} / \mathrm{L} \cdot \mathrm{d})$, removal efficiency of ammoniacal nitrogen (98.7-99.8\%), TDP (41.0-62.5\%) and TDN (60.3-76.9\%) were 7.33-19, 1.21-1.23, 2.70-2.87 and 1.03-1.32 times higher than non-stripped anaerobically-digested PWs. Furthermore, despite the high concentration of SCOD, the biomass productivity was 1.4-4.4 times higher than BG-11 that did not contain any organic substances. However, NaOCl treatment did not remove ammonia effectively, and microalgal cells did not grow well. Therefore, it was concluded that efficient biomass production and nutrients removal could be accomplished by air-stripping high-strength wastewater.

\section{Acknowledgments}

This study was supported by Korea Ministry of Environment as "Global Top Project” (Project No.: 2016002190007).

\section{References}

1. Ji M, Abou-Shanab RA, Hwang J, et al. Removal of nitrogen and phosphorus from piggery wastewater effluent using the green microalga Scenedesmus obliquus. J. Environ. Eng. 2013;139:1198-1205.

2. Ji M, Kim H, Sapireddy VR, et al. Simultaneous nutrient removal and lipid production from pretreated piggery wastewater by Chlorella vulgaris YSW-04. Appl. Microbiol. Biotechnol. 2013;97:2701-2710.

3. ECOREA. Livestock manure statistics [Internet]. Ministry of Environment Republic of Korea; [cited 16 May 2018]. Available from: http://www.me.go.kr/home/file/readDownloadFile.do?fileId= 150181\&fileSeq $=1$.

4. Park J, Jin HF, Lim BR, Park KY, Lee K. Ammonia removal from anaerobic digestion effluent of livestock waste using green alga Scenedesmus sp. Bioresour. Technol. 2010;101:8649-8657.

5. Zhu L, Wang Z, Shu Q, et al. Nutrient removal and biodiesel production by integration of freshwater algae cultivation with piggery wastewater treatment. Water Res. 2013;47:4294-4302.

6. Zhang L, Jahng D. Enhanced anaerobic digestion of piggery wastewater by ammonia stripping: Effects of alkali types. $J$. Hazard. Mater. 2010;182:536-543.

7. Zhang L, Lee Y, Jahng D. Ammonia stripping for enhanced biomethanization of piggery wastewater. J. Hazard. Mater. 2012;199:36-42.

8. Cheng J, Liu B. Swine wastewater treatment in anaerobic di- gesters with floating medium. Trans. ASAE 2002;45:799.

9. Noike T, Goo I, Matsumoto H, Miyahara T. Development of a new type of anaerobic digestion process equipped with the function of nitrogen removal. Water Sci. Technol. 2004;49: 173-179.

10. Carney K, Rodgers M, Lawlor P, Zhan X. Treatment of separated piggery anaerobic digestate liquid using woodchip biofilters. Environ. Technol. 2013;34:663-670.

11. Kwon G, Kang J, Nam J, Kim Y, Jahng D. Recovery of ammonia through struvite production using anaerobic digestate of piggery wastewater and leachate of sewage sludge ash. Environ. Technol. 2018;39:831-842.

12. Jaafarzadeh Haghighi Fard NA, Jorfi S, Ahmadi M, Mirali S, Kujlu R. Treatment of mature landfill leachate by chemical precipitation and Fenton advanced oxidation process. Environ. Health Eng. Manage. J. 2016;3:35-40.

13. Aslan S, Kapdan IK. Batch kinetics of nitrogen and phosphorus removal from synthetic wastewater by algae. Ecol. Eng. 2006;28:64-70.

14. Olguín EJ, Galicia S, Mercado G, Pérez T. Annual productivity of Spirulina (Arthrospira) and nutrient removal in a pig wastewater recycling process under tropical conditions. J. Appl. Phycol. 2003;15:249-257.

15. Mennaa FZ, Arbib Z, Perales JA. Urban wastewater treatment by seven species of microalgae and an algal bloom: Biomass production, $\mathrm{N}$ and $\mathrm{P}$ removal kinetics and harvestability. Water Res. 2015;83:42-51.

16. Posadas E, Morales M, Gomez C, Acién FG, Muñoz R. Influence of $\mathrm{pH}$ and $\mathrm{CO}_{2}$ source on the performance of microalgae-based secondary domestic wastewater treatment in outdoors pilot raceways. Chem. Eng. J. 2015;265:239-248.

17. Hoffmann JP. Wastewater treatment with suspended and nonsuspended algae. J. Phycol. 1998;34:757-763.

18. García J, Green BF, Lundquist T, Mujeriego R, HernándezMariné M, Oswald WJ. Long term diurnal variations in contaminant removal in high rate ponds treating urban wastewater. Bioresour. Technol. 2006;97:1709-1715.

19. Li Y, Chen Y, Chen P, et al. Characterization of a microalga Chlorella sp. well adapted to highly concentrated municipal wastewater for nutrient removal and biodiesel production. Bioresour. Technol. 2011;102:5138-5144.

20. Wang L, Li Y, Chen P, et al. Anaerobic digested dairy manure as a nutrient supplement for cultivation of oil-rich green microalgae Chlorella sp. Bioresour. Technol. 2010;101:2623-2628.

21. Wang L, Min M, Li Y, et al. Cultivation of green algae Chlorella sp. in different wastewaters from municipal wastewater treatment plant. Appl. Biochem. Biotechnol. 2010;162:1174-1186.

22. Xu M, Xu S, Bernards M, Hu Z. Evaluation of high density algal cultivation for secondary wastewater polishing. Water Environ. Res. 2016;88:47-53.

23. Shi J, Podola B, Melkonian M. Removal of nitrogen and phosphorus from wastewater using microalgae immobilized on twin layers: An experimental study. J. Appl. Phycol. 2007;19:417-423.

24. Kim HC, Choi WJ, Maeng SK, Kim HJ, Kim HS, Song KG. Ozonation of piggery wastewater for enhanced removal of contaminants by $S$. quadricauda and the impact on organic characteristics. Bioresour. Technol. 2014;159:128-135. 
25. Zhen-Feng S, Xin L, Hong-Ying H, Yin-Hu W, Tsutomu N. Culture of Scenedesmus sp. LX1 in the modified effluent of a wastewater treatment plant of an electric factory by photo-membrane bioreactor. Bioresour. Technol. 2011;102:7627-7632.

26. Xin L, Hong-ying H, Ke G, Ying-xue S. Effects of different nitrogen and phosphorus concentrations on the growth, nutrient uptake, and lipid accumulation of a freshwater microalga Scenedesmus sp. Bioresour. Technol. 2010;101:5494-5500.

27. Ruiz-Marin A, Mendoza-Espinosa LG, Stephenson T. Growth and nutrient removal in free and immobilized green algae in batch and semi-continuous cultures treating real wastewater. Bioresour. Technol. 2010;101:58-64.

28. Converti A, Casazza AA, Ortiz EY, Perego P, Del Borghi M. Effect of temperature and nitrogen concentration on the growth and lipid content of Nannochloropsis oculata and Chlorella vulgaris for biodiesel production. Chem. Eng. Process. 2009;48: 1146-1151.

29. Khanh N, Kitaya Y, Xiao L, Endo R, Shibuya T. Selection of microalgae suitable for culturing with digestate from methane fermentation. Environ. Technol. 2013;34:2039-2045.

30. Azov Y, Goldman JC. Free ammonia inhibition of algal photosynthesis in intensive cultures. Appl. Environ. Microbiol. 1982;43: 735-739.

31. Chen R, Li R, Deitz L, Liu Y, Stevenson RJ, Liao W. Freshwater algal cultivation with animal waste for nutrient removal and biomass production. Biomass Bioenerg. 2012;39:128-138.

32. Crofts AR. Amine uncoupling of energy transfer in chloroplasts. I. Relation to ammonium ion uptake. J. Biol. Chem. 1967;242: 3352-3359.

33. Ohmori M, Ohmori K, Strotmann H. Inhibition of nitrate uptake by ammonia in a blue-green alga, Anabaena cylindrica. Arch. Microbiol. 1977;114:225-229.

34. Zhu L, Wang Z, Takala J, et al. Scale-up potential of cultivating Chlorella zofingiensis in piggery wastewater for biodiesel production. Bioresour. Technol. 2013;137:318-325.

35. Wang H, Xiong H, Hui Z, Zeng X. Mixotrophic cultivation of Chlorella pyrenoidosa with diluted primary piggery wastewater to produce lipids. Bioresour. Technol. 2012;104:215-220.

36. Kim J, Cho JH, Noh KH, Nam G, Hwang S. Effect of high free ammonia concentration on microalgal growth and substrate uptake. J. Korean Soc. Water Wastewater 2016;30:715-723.

37. Halling-Sørensen B, Jorgensen SE. The removal of nitrogen compounds from wastewater. Amsterdam: Elsevier Science; 1993.

38. Hussain S, Aziz HA, Isa MH, Adlan MN, Asaari FA. Physico-chemical method for ammonia removal from synthetic wastewater using limestone and GAC in batch and column studies. Bioresour. Technol. 2007;98:874-880.

39. Bonmatı A, Flotats X. Air stripping of ammonia from pig slurry: Characterisation and feasibility as a pre-or post-treatment to mesophilic anaerobic digestion. Waste Manage. 2003;23:261-272.

40. Cheng H, Tian G, Liu J. Enhancement of biomass productivity and nutrients removal from pretreated piggery wastewater by mixotrophic cultivation of Desmodesmus sp. CHX1. Desalin. Water Treat. 2013;51:7004-7011.

41. Moheimani NR, McHenry MP, de Boer K, Bahri P, eds. Biomass and biofuels from microalgae. In: Biofuel biorefinery technologies. Springer International Publishing; 2015.
42. Depraetere O, Foubert I, Muylaert K. Decolorisation of piggery wastewater to stimulate the production of Arthrospira platensis. Bioresour. Technol. 2013;148:366-372.

43. Markou G, Chatzipavlidis I, Georgakakis D. Cultivation of Arthrospira (Spirulina) platensis in olive-oil mill wastewater treated with sodium hypochlorite. Bioresour. Technol. 2012;112: 234-241.

44. Qin L, Shu Q, Wang Z, et al. Cultivation of Chlorella vulgaris in dairy wastewater pretreated by UV irradiation and sodium hypochlorite. Appl. Biochem. Biotechnol. 2014;172:1121-1130.

45. Dahmani S, Zerrouki D, Ramanna L, Rawat I, Bux F. Cultivation of Chlorella pyrenoidosa in outdoor open raceway pond using domestic wastewater as medium in arid desert region. Bioresour. Technol. 2016;219:749-752.

46. Choi H. Intensified production of microalgae and removal of nutrient using a microalgae membrane bioreactor (MMBR). Appl. Biochem. Biotechnol. 2015;175:2195-2205.

47. Mujtaba G, Lee K. Treatment of real wastewater using co-culture of immobilized Chlorella vulgaris and suspended activated sludge. Water Res. 2017;120:174-184.

48. Amaral P, Fernandes D, Tavares A, et al. Decolorization of dyes from textile wastewater by trametes versicolor. Environ. Technol. 2004;25:1313-1320.

49. American Public Health Association, American Water Works Association, Water Pollution Control Federation, Water Environment Federation. Standard methods for the examination of water and wastewater. American Public Health Association; 2005.

50. Tam N, Wong Y. Effect of ammonia concentrations on growth of Chlorella vulgaris and nitrogen removal from media. Bioresour. Technol. 1996;57:45-50.

51. Markou G, Georgakakis D. Cultivation of filamentous cyanobacteria (blue-green algae) in agro-industrial wastes and wastewaters: A review. Appl. Energ. 2011;88:3389-3401.

52. Martin C, De la Noüe J, Picard G. Intensive cultivation of freshwater microalgae on aerated pig manure. Biomass 1985;7:245-259.

53. Pressley TA, Bishop DF, Roan SG. Ammonia-nitrogen removal by breakpoint chlorination. Environ. Sci. Technol. 1972;6:622-628.

54. Liang Y, Hong HC, Dong LH, Lan CY, Han BP, Wong MH. Sources and properties of natural organic matter (NOM) in water along the Dongjiang River (the source of Hong Kong's drinking water) and toxicological assay of its chlorination by-products. Arch. Environ. Contam. Toxicol. 2008;54:597-605.

55. Yang M, Liu J, Zhang X, Richardson SD. Comparative toxicity of chlorinated saline and freshwater wastewater effluents to marine organisms. Environ. Sci. Technol. 2015;49:14475-14483.

56. Martínez ME, Camacho F, Jiménez J, Espinola J. Influence of light intensity on the kinetic and yield parameters of Chlorella pyrenoidosa mixotrophic growth. Process Biochem. 1997;32:93-98.

57. Silaban A, Bai R, Gutierrez-Wing MT, Negulescu II, Rusch KA Effect of organic carbon, C:N ratio and light on the growth and lipid productivity of microalgae/cyanobacteria coculture. Eng. Life Sci. 2014;14:47-56.

58. Yan C, Zhang L, Luo X, Zheng Z. Effects of various LED light wavelengths and intensities on the performance of purifying synthetic domestic sewage by microalgae at different influent C/N ratios. Ecol. Eng. 2013;51:24-32. 
59. Li C, Yu Y, Zhang D, Liu J, Ren N, Feng Y. Combined effects of carbon, phosphorus and nitrogen on lipid accumulation of Chlorella vulgaris in mixotrophic culture. J. Chem. Technol. Biotechnol. 2016;91:680-684.

60. Liang Y, Sarkany N, Cui Y. Biomass and lipid productivities of Chlorella vulgaris under autotrophic, heterotrophic and mixotrophic growth conditions. Biotechnol. Lett. 2009;31:1043-1049.

61. Zeng Z, Zheng P, Ding A, Zhang M, Abbas G, Li W. Source analysis of organic matter in swine wastewater after anaerobic digestion with EEM-PARAFAC. Environ. Sci. Pollut. Res. 2017;24:6770-6778.

62. Redfield AC. The biological control of chemical factors in the environment. Am. Sci. 1958;46:230A-221.

63. Lalucat J, Imperial J, Pares R. Utilization of light for the assimilation of organic matter in Chlorella sp. VJ79. Biotechnol. Bioeng. 1984;26:677-681.

64. Kumar MS, Miao ZH, Wyatt SK. Influence of nutrient loads, feeding frequency and inoculum source on growth of Chlorella vulgaris in digested piggery effluent culture medium. Bioresour. Technol. 2010;101:6012-6018.

65. ROK MOE: Enforcement decree of the water quality and aquatic ecosystem conservation act [Internet]. Republic of Korea Ministry of Environment [cited 16 May 2018]. Available from: http://www.law.go.kr/LSW/flDownload.do?flSeq=36219185\&f $\mathrm{lNm}=\% 5 \mathrm{~B} \% \mathrm{~EB} \% \mathrm{~B} 3 \% 84 \% \mathrm{ED} \% 91 \% 9 \mathrm{C}+13 \% 5 \mathrm{D}+\% \mathrm{EC} \% 88 \% 9$ 8\%ЕC\%A7\%88\%ЕC\%98\%A4\%ЕС\%97\%BC\%ЕВ\%АC\%ВC\%Е C\%A7\%88\%ЕC\%9D\%98+\%EB\%B0\%B0\%EC\%B6\%9C\%ED\% 97\%88\%ЕC\%9A\%А9\%ЕА\%В8\%В0\%ЕС\%А4\%80\%28\%ЕС\% А0\%9С34\%ЕC\%A1\%B0+\%ЕA\%B4\%80\%ЕB\%А0\%А8\%29\% $0 \mathrm{~A}$.

66. Gao F, Yang Z, Li C, Wang YJ, Jin WH, Deng YB. Concentrated microalgae cultivation in treated sewage by membrane photobioreactor operated in batch flow mode. Bioresour. Technol. 2014;167:441-446.

67. Sun X, Wang C, Li Z, Wang W, Tong Y, Wei J. Microalgal cultivation in wastewater from the fermentation effluent in riboflavin (B2) manufacturing for biodiesel production. Bioresour. Technol. 2013;143:499-504.

68. Farooq W, Lee Y, Ryu B, et al. Two-stage cultivation of two Chlorella sp. strains by simultaneous treatment of brewery wastewater and maximizing lipid productivity. Bioresour. Technol. 2013;132:230-238.

69. Wilkie AC, Mulbry WW. Recovery of dairy manure nutrients by benthic freshwater algae. Bioresour. Technol. 2002;84:81-91.

70. Cho S, Lee N, Park S, et al. Microalgae cultivation for bioenergy production using wastewaters from a municipal WWTP as nutritional sources. Bioresour. Technol. 2013;131:515-520.
71. González LE, Cañizares RO, Baena S. Efficiency of ammonia and phosphorus removal from a colombian agroindustrial wastewater by the microalgae Chlorella vulgaris and Scenedesmus dimorphus. Bioresour. Technol. 1997;60:259-262.

72. Zhu L, Hiltunen E, Shu Q, Zhou W, Li Z, Wang Z. Biodiesel production from algae cultivated in winter with artificial wastewater through $\mathrm{pH}$ regulation by acetic acid. Appl. Energ. 2014;128:103-110.

73. De-Bashan LE, Moreno M, Hernandez J, Bashan Y. Removal of ammonium and phosphorus ions from synthetic wastewater by the microalgae Chlorella vulgaris coimmobilized in alginate beads with the microalgae growth-promoting bacterium Azospirillum brasilense. Water Res. 2002;36:2941-2948.

74. Martmez M, Sánchez S, Jimenez J, El Yousfi F, Munoz L. Nitrogen and phosphorus removal from urban wastewater by the microalga Scenedesmus obliquus. Bioresour. Technol. 2000;73:263-272.

75. Renuka N, Sood A, Ratha SK, Prasanna R, Ahluwalia AS. Evaluation of microalgal consortia for treatment of primary treated sewage effluent and biomass production. J. Appl. Phycol. 2013;25:1529-1537.

76. Qin L, Wang Z, Sun Y, et al. Microalgae consortia cultivation in dairy wastewater to improve the potential of nutrient removal and biodiesel feedstock production. Environ. Sci. Pollut. Res. 2016;23:8379-8387.

77. Su Y, Mennerich A, Urban B. Coupled nutrient removal and biomass production with mixed algal culture: Impact of biotic and abiotic factors. Bioresour. Technol. 2012;118:469-476.

78. Kim H, Choi WJ, Chae AN, Park J, Kim HJ, Song KG. Evaluating integrated strategies for robust treatment of high saline piggery wastewater. Water Res. 2016;89:222-231.

79. Bosoi CR, Rose CF. Identifying the direct effects of ammonia on the brain. Metab. Brain Dis. 2009;24:95-102.

80. Gallert C, Bauer S, Winter J. Effect of ammonia on the anaerobic degradation of protein by a mesophilic and thermophilic biowaste population. Appl. Microbiol. Biotechnol. 1998;50:495-501.

81. Rajagopal R, Massé DI, Singh G. A critical review on inhibition of anaerobic digestion process by excess ammonia. Bioresour. Technol. 2013;143:632-641.

82. Smolders AJP, den Hartog C, van Gestel CBL, Roelofs JGM. The effects of ammonium on growth, accumulation of free amino acids and nutritional status of young phosphorus deficient Stratiotes aloides plants. Aquat. Bot. 1996;53:85-96.

83. Wang $\mathrm{H}, \mathrm{Hu} \mathrm{Z}$, Xiao B, Cheng Q, Li F. Ammonium nitrogen removal in batch cultures treating digested piggery wastewater with microalgae Oedogonium sp. Water Sci. Technol. 2013;68 269-275 